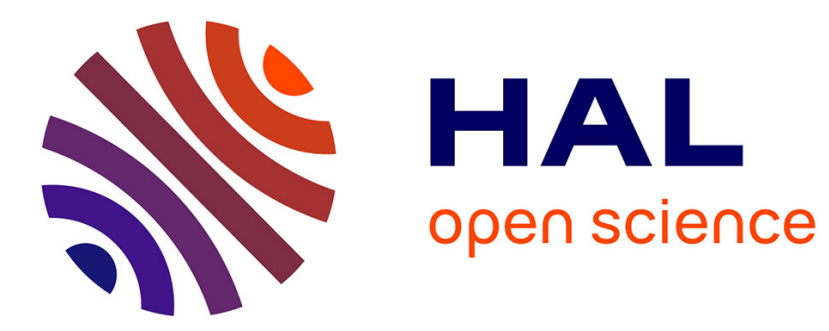

\title{
Genetic differences among isolates from dairy ruminant species: a single-dye DNA micro-array approach
}

E. Vautor, V. Magnone, G. Rios, K. Le Brigand, D. Bergonier, G. Lina, H. Meugnier, P. Barbry, Régis Thiery, Michel Pépin

\section{- To cite this version:}

E. Vautor, V. Magnone, G. Rios, K. Le Brigand, D. Bergonier, et al.. Genetic differences among isolates from dairy ruminant species: a single-dye DNA micro-array approach. Veterinary Microbiology, 2008, 133 (1-2), pp.105. 10.1016/j.vetmic.2008.06.006 . hal-00532442

HAL Id: hal-00532442

https://hal.science/hal-00532442

Submitted on 4 Nov 2010

HAL is a multi-disciplinary open access archive for the deposit and dissemination of scientific research documents, whether they are published or not. The documents may come from teaching and research institutions in France or abroad, or from public or private research centers.
L'archive ouverte pluridisciplinaire HAL, est destinée au dépôt et à la diffusion de documents scientifiques de niveau recherche, publiés ou non, émanant des établissements d'enseignement et de recherche français ou étrangers, des laboratoires publics ou privés. 


\section{Accepted Manuscript}

Title: Genetic differences among Staphylococcus aureus isolates from dairy ruminant species: a single-dye DNA micro-array approach

Authors: E. Vautor, V. Magnone, G. Rios, K. Le Brigand, D. Bergonier, G. Lina, H. Meugnier, P. Barbry, R. Thiéry, M.

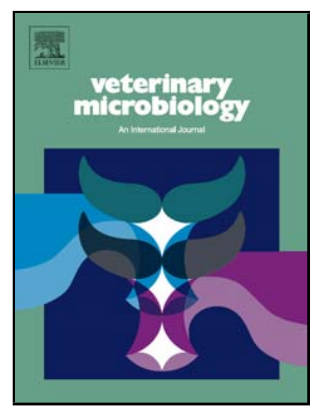

Pépin

PII:

DOI:

Reference:

S0378-1135(08)00218-6

doi:10.1016/j.vetmic.2008.06.006

VETMIC 4066

To appear in: $\quad$ VETMIC

Received date: $\quad 3-1-2008$

Revised date: $\quad$ 2-6-2008

Accepted date: $\quad 4-6-2008$

Please cite this article as: Vautor, E., Magnone, V., Rios, G., Le Brigand, K., Bergonier, D., Lina, G., Meugnier, H., Barbry, P., Thiéry, R., Pépin, M., Genetic differences among Staphylococcus aureus isolates from dairy ruminant species: a single-dye DNA microarray approach, Veterinary Microbiology (2007), doi:10.1016/j.vetmic.2008.06.006

This is a PDF file of an unedited manuscript that has been accepted for publication. As a service to our customers we are providing this early version of the manuscript. The manuscript will undergo copyediting, typesetting, and review of the resulting proof before it is published in its final form. Please note that during the production process errors may be discovered which could affect the content, and all legal disclaimers that apply to the journal pertain. 
1 Genetic differences among Staphylococcus aureus

2 isolates from dairy ruminant species: a single-dye

\section{DNA micro-array approach.}

M. Pépin ${ }^{\mathrm{a}}$

${ }^{a}$ Agence Française de Sécurité Sanitaire des Aliments (AFSSA), Unité Pathologie des Petits

${ }^{b}$ CNRS and ${ }^{c}$ Université de Nice-Sophia Antipolis, Institut de Pharmacologie Moléculaire et

${ }^{d}$ Ecole Nationale Vétérinaire (ENVT), UMR 1225 INRA-ENVT Interactions Hôtes Agents-

' INSERM U851, Centre National de Référence des Staphylocoques, Université Lyon 1,

Hospices Civils de Lyon, Lyon, France

*Corresponding author: AFSSA Sophia-Antipolis, 105 route des Chappes, BP111, F-06902 


\section{Abstract}

Staphylococcus aureus is recognized worldwide as a major pathogen causing clinical or subclinical intramammary infections in lactating sheep, goats and cows. The present study was carried out to compare $65 \mathrm{~S}$. aureus isolates mainly obtained from nasal carriage and subclinical mastitis in dairy sheep and 43 isolates obtained from subclinical mastitis from 22 goats and 21 cows. A DNA microarray, containing probes against 190 true or putative 29 virulence factors, was used to detect the presence of the virulence genes. Their 30 presence/absence was independently assessed by PCR for the genes of interest. Sheep isolates obtained from the nostrils or the udders did not show any significant tissue specific virulence factor. The dominant pulse-field electrophoresis profile (OV/OV'), associated with spa clonal complex spa-CC1773, matched mainly with the agr group III and was only found in ovine and caprine isolates. This clone was more specifically characterized by the prevalence of the following virulence genes: lpl4, ssl6, bsaA1, bsaB, bsaP, SAV0812. Moreover, seven virulence-associated genes (lpl1, sel, sec, tst, lukF-PV like component, lukM, SAV0876) were associated with isolates from small ruminants, while the $e g c$ cluster, $f h u \mathrm{D} 1, a b \mathrm{iF}$ and

38 SAV2496 with bovine isolates. This genomic study suggests the existence of lineage- and 39 host-specific genes leading to the development of host-specific pathogenic traits of

\section{$40 \quad$ Staphylococcus aureus isolates.}

Keywords: Staphylococcus aureus; mastitis, host-specific genes; sheep; goats; cows 


\section{Introduction}

Staphylococus aureus is an important cause of mammary gland disease in dairy ruminant species: sheep, goats, cows (Mork et al., 2005a). As in humans and probably in cows and goats, the nasal carriage of $S$. aureus in sheep is frequent . The upper respiratory tract is a possible reservoir for the contamination of udders and milk in dairy farms (Vautor et al., 2005). For dairy cows and sheep, it has been shown that several S. aureus strains are shared within and between many herds, even at a long distance. The existence of such dominant strains of S. aureus suggests that these clones have special properties, in particular special virulence-associated genes to overcome host defenses and to establish a successful intramammary infection in ewes, goats or in cows (Stephan et al., 2001; Vautor et al., 2003) .

54 Although many putative virulence factors have been identified in S. aureus by whole-genome 55 sequencing (Kuroda et al, 2001), the potential differences of pathogenicity among isolates from naturally occurring infections remains largely unknown.

57 The accessory gene regulator (agr) locus of S. aureus encodes a two-component signal transduction system that leads to down-regulation of surface proteins and up-regulation of secreted proteins during growth in vitro. Four allelic groups of agr that are related to the genetic background and to the presence of virulence factors have been characterized in human strains (Jarraud et al., 2002). However the relative distribution of the agr groups in S. aureus isolates obtained from dairy species with diagnosed mastitis, is still unknown.

63 In this study, 108 S. aureus isolates were obtained from sheep, goats and cows. A single64 dye microarray approach was used: (i) to assess the presence of 190 virulence genes or alleles 65 (e.g. agr groups, toxin genes, exoenzyme genes,...) in S. aureus isolates that possess distinct PFGE profiles and spa types, (ii) to assess whether the nasal carriage isolates from sheep had specific adaptative virulent genes in comparison to udder isolates, (iii) to identify genetic 
polymorphism of $S$. aureus associated with the relative host specificity in cows, goats and sheep.

\section{Materials and methods}

2.1. Bacterial isolates A total of 108 S. aureus isolates were included in this study. The isolates from dairy sheep $(n=65)$ were mainly collected (i) during two field surveys in the southeast of France in farms without any obvious epidemiological link (Vautor et al., 2003; Vautor, et al., 2005) and (ii) from field surveys in two other regions specialized in sheep dairy production located in the southwest of France (Roquefort and Atlantic Pyrenees areas) between 1995 to 2003. They were obtained from animals presenting subclinical mastitis $(n=$ $34)$, nasal carriage $(n=21)$ and other clinical features or origins $(n=10)$.

The isolates from goats $(n=22)$ and dairy cows $(n=21)$ were collected from subclinical mastitis cases throughout the main French areas of dairy production, in farms without any epidemiological link. The bovine strain V329 from Spain was kindly provided by Dr. José R. Penadés. Seventy-five dairy farms were involved in the study (32 for sheep, 22 for goats and 21 for cows).

All the isolates were coagulase-positive and were confirmed as $S$. aureus by PCR performed on the 23S rDNA gene (Straub et al., 1999).

\subsection{PFGE (pulsed-field gel electrophoresis)}

Briefly, a contour clamped homogeneous electrophoresis technique (CHEF) on the GenePath $^{\mathrm{TM}}$ system (Bio-Rad Laboratories, Hercules, CA, USA) was used according to the manufacturer's instructions. The DNA was digested by SmaI. The Isolates of $S$. aureus were 
94 classified in groups of identical or related strains by visual comparison of patterns. All the strains with a pulsotype closely or possibly related to OV were named OV' (less than 6-band differences). The Strains with patterns of with more than 6-band differences were classified as unrelated or different and named "not OV/OV" "(Vautor et al., 2003; Vautor et al., 2005). primers spa-1113f (5' TAA AGA CGA TCC TTC GGT GAG C 3') and spa-1514r (5' CAG CAG TAG TGC CGT TTG CTT 3'), and sequenced. Applying the recently developed algorithm BURP (Based Upon Repeat Patterns) the spa types (spa-t) were clustered into different groups with a calculated cost between members of a group less or equal to 5 . The BURP spa clonal complexes (spa-CCs) were automatically assigned by Ridom Staph Type software using the code system described on the Ridom SpaServer website (www.spa.ridom.de).

\subsection{Single-dye DNA microarrays}

2.4.1. DNA extraction. The isolates were subcultured in trypticase agar soy plates and incubated overnight at $37^{\circ} \mathrm{C}$ in Luria-Bertani broth. Bacterial cells were harvested $(1.5 \mathrm{ml})$

114 and lysed in a solution of lysozyme $\left(20 \mathrm{mg} \cdot \mathrm{ml}^{-1}\right)$ and lysostaphine $\left(200 \mu \mathrm{g} \cdot \mathrm{ml}^{-1}\right)$. DNA was extracted with the DNeasy®Tissue kit (Qiagen, Courtaboeuf, France) according to the manufacturer's recommendations. The nucleic acid concentration was determined by measuring the absorbance with a spectrophotometer. 
system kit (Invitrogen, Cergy Pontoise, France) for 3 hours at $37^{\circ} \mathrm{C}$. The Labelled DNA was then purified from the reaction mixture by using the QIAquick PCR purification kit (Qiagen, Courtaboeuf, France), following the manufacturer's protocol. The bound DNA was eluted from the column with $53 \mu \mathrm{l}$ DNAase-free distilled water and stored at $-20^{\circ} \mathrm{C}$ until used for hybridization.

2.4.3. Array design. The array was designed to include $S$. aureus genes that are truly or potentially associated to virulence: toxins, leukocidin, coagulase, adhesins, proteases, nucleases, lipoproteins, lipases, capsular polysaccharides, etc. They were identified in the genome of strain Mu50, Genbank accession numberBA000017 (Kuroda et al., 2001). The selected genes were completed by 28 additional virulence-associated genes from other $S$. aureus strains. Details are given in the supplemental material (Appendix A). Positive and negative control genes were included. Single oligonucleotide probes were designed for each gene (188 genes) using the OligoArray program (Rouillard et al., 2002). Each probe was a 65 mer with a calculated $\mathrm{Tm}$ of approximately $83^{\circ} \mathrm{C}$ and with a minimal internal structure. The identification of the genes and the probe's sequences are available in the public database ArrayExpress ${ }^{\circledR}$ under the accession number E-TABM-288 (Brazma et al., 2003).

\subsubsection{Printing and slide Processing. The oligonucleotides were printed on UltraGAPS ${ }^{\mathrm{TM}}$} Coated Slides (Corning, Schiphol-Rijk, The Netherlands) by means of a ChipWriter Pro (Bio-Rad Laboratories, Richmond, California). Two replicates were printed for each oligonucleotide and the pattern was printed to each slide in duplicate. The spotting solution alone was printed as a negative control.

2.4.5. Slide prehybridization. Each slide was prehybridized at $42^{\circ} \mathrm{C}$ for $45 \mathrm{~min}$ in a solution $(5 \times \mathrm{SSC}, 0.1 \% \mathrm{SDS}$ and $0.1 \mathrm{mg} / \mathrm{ml} \mathrm{BSA})$, transfered twice in a solution $(0.1 \times \mathrm{SSC})$ at room temperature, immersed $30 \mathrm{sec}$ in purified water, and finally dried by centrifugation (1600 rpm for $2 \mathrm{~min})$. 
DNA (target). The target was denatured by heating at $95^{\circ} \mathrm{C}$ for $5 \mathrm{~min}$ and allowed to cool down to room temperature before the addition of $12 \mu 1$ of the hybridization solution $(35 \%$

148 formamide, $5 \times$ SSC, $0.1 \%$ SDS) in a $30 \mu$ final volume. The slides were hybridized under a $14924 \times 50 \mathrm{~mm}$ glass coverslip. They were incubated for $16 \mathrm{~h}$ at $42^{\circ} \mathrm{C}$ in hybridization chambers 150 (Corning, Schiphol-Rijk, The Netherlands) protected from the light. Following hybridization, the slides were immersed in a solution $(2 \times \mathrm{SSC}, 0.1 \% \mathrm{SDS})$ at $42^{\circ} \mathrm{C}$ until the coverslip moved freely away from the slide. The slides were incubated twice in the same solution at $42^{\circ} \mathrm{C}$ for $5 \mathrm{~min}$. Then, they were washed 4 times with $0.1 \times \mathrm{SSC}$ at room temperature. After a final wash in $0.01 \times \mathrm{SSC}$ for 10 seconds, the slides were dried by centrifugation at $1600 \mathrm{rpm}$ during $2 \mathrm{~min}$.

The arrays were scanned in the red channel of a Gene Pix ${ }^{\circledR}$ autoloader 4200 AL scanner or a Gene Pix ${ }^{\circledR}$ 4000B scanner (Molecular Devices Corporation, Sunnyvale, California). The images were processed using GenePix Pro ${ }^{\circledR}$ version 6.0 (Molecular Devices Corporation, Sunnyvale, California). Briefly, the background signals were subtracted and the medians of the four spots were calculated. A cut-off value was determined for each gene in order to classify each gene as "present", "absent or divergent" or "not interpretable". The cut-off values were determined independently for each gene with the data of the positive gene (mainly S. aureus Mu50 strain) and the negative data (Plasmid pK 0311). Basically, the positive results were defined for each gene by the results of the median of the four spots fluorescence intensity superior to the data of the positive gene minus the standard deviation. The negative results were defined by a results of the median of the intensity inferior to the negative data plus the standard deviation. Between these results the data were considered "not interpretable". The results were ascertained by PCR for the genes of interest and the cut off adapted. For each gene, the details of each cut-off are given in the supplementary material (Appendix A). 
2.4.7. Validation of the microarray data. The strain Mu50, 7 strains with PCR positive genes (cna, agrI, agrII, agrIII, agrIV, seb, seh, sea, sed, see, seg, sei, eta, etb) and strains with known phenotypic characteristic (coagulase) were used as positive controls. The plasmid pKO311 from $S$. aureus strain F5 was kindly provided by Dr. K. Omoe, Japan, and was used as a negative control for all the genes except for $s e j$. The reproducibility was estimated by carrying out two independent labeling and hybridization experiments on 15 isolates in duplicate. The reproducibility of the data obtained with the strain Mu50 were evaluated over 7 independent experiments. PCR tests were performed for the $108 \mathrm{~S}$. aureus isolates on particular loci, genes or alleles to confirm the microarray data by using primers described in the literature: $c o a$ (Goh et al., 1992), $c l f \mathrm{~B}, c n a, s d r \mathrm{C}-\mathrm{E}, \operatorname{ssp} \mathrm{A}(\mathrm{V} 8)$, icaA, map/eap (Peacock et al., 2002), eta, etb, tst (Becker et al., 1998), sak (van Wamel et al., 2006), fnbB (Kuhn et al., 2006), lukS-PV-lukF-PV, lukE-lukD, agr group I-III (Gilot et al., 2002), sea, seb-c, sec, sed, see, seg, seh, sei, sej (Monday et al., 1999), sek, sel, sem, sen, seo, seq (Smyth et al., 2005). PCR results for a few genes were confirmed by using primers designed with Primer3 (Rozen et al., 2000): fnbB, sdrD, SAV0879, SAV2496. Moreover, lukM gene (Jarraud et al., 2002) and agr group IV allele (Gilot et al., 2002) were analyzed only by PCR.

A subset of 24 genes giving significantly different hybridization signals between isolates was also verified by PCR using Primer3-designed primers (lpl1, lpl4, ssl6, bsaA1, bsaB, bsaP, SAV0812, lukF-PV like component, SAV0876, fhuD1, abiF, SAV2496, $\psi$ ent1 and $\psi$ ent2 ) or with primers found in the literature for $a g r$ group III (Gilot et al., 2002), lukM (Jarraud et al., 2002), sec (Monday et al., 1999), tst (Becker et al., 1998), seg, sei (Monday et al., 1999), sel, sem, sen, seo (Smyth et al, 2005). The primer sequences used in PCRs are listed in the supplementary data (appendix A).

2.4.8. Statistical analysis. The distribution of putative virulence genes or alleles among $S$. aureus isolates obtained from different hosts was compared using Fisher's exact test. The 2tail $p$-value was calculated and $p$ values less than 0.05 were considered significant . 
The microarray data are available in the public database ArrayExpress ${ }^{\circledR}$ under the accession number E-TABM-288 (Brazma et al., 2003).

\section{Results}

All raw data from this study are given in the supplementary material (Appendix A).

\subsection{PFGE patterns, spa-clonal complexes and agr groups.}

All the $S$. aureus strains included in this study were classified using PFGE, spa typing, agr groups and compared with the dominant PFGE pulsotype found in the ewe suclinical mastitis isolates of the southeast of France. The PFGE patterns, classified as OV/OV' or not OV/OV'

(Vautor et al, 2003), the spa-clonal complexes (spa-CC), and the agr groups are shown in

Table 1 . The genetically related OV and OV' PFGE profiles were only found in small ruminant isolates. These PFGE profiles $(n=45)$, clustered as a PFGE group, belonging mainly to the spa-clonal complex 1773 except for two strains that belong to spa-CC 2678 and a singleton (spa-type 3572).

214 In this study we had incorporated the spa types with two repeats in the spa clustering 215 because 20 isolates out of 108 had only two spa repeats. Thus reliable deduction about the 216 ancestries could be made from these types. The spa-CC 1773 clustered different spa-types $217(1736,1773,3568,3569,3570,3571,3575,3576,524,529,605)$ ranging from 2 to 9 repeats. 218 The dominant repeat were for spa-type 1773: 04-82-17-25-17, spa-type 3568: 04-39-17 and spa-type 524: 04-17. The occurrence of the spa-types detected in this study was very low $(0,02 \%)$, when compared with the 3605 spa-types present in the Ridom SpaServer database (spaserver2.ridom.de). This database contains 53936 strains from 48 countries mostly from human. 
The PFGE technique was more discriminant than spa typing. For example, many of the not OV/OV' PFGE profiles were incorporated in the same spa clonal complex spa-CC 2678 (data not shown). The strains depicting OV/OV' PFGE profiles (and spa-CC 1773) were 226 predominant in the southeast of France. This subset of strains was further used for the comparative genetic study between subclinical and nasal carriage isolates.

In the southwest areas where dairy ewe husbandry is practiced, the OV and OV' PFGE profiles were minor ones. In this area we found 2 isolates with OV/OV' PFGE profiles associated with spa-CC 1773. A third isolate did not show a OV/OV' profile but belonged to spa-CC 1773.

Among the bovines isolates, we found 7 strains associated with the spa-clonal complex 1773 [spa-type $524(\mathrm{n}=4) ;$ spa-type $529(\mathrm{n}=1) ;$ spa-type $1736(\mathrm{n}=1)$; spa-type $605(\mathrm{n}=$ 1)]. The spa types $1773,3568,3569,3570,3571,3574,3575,3576$ clustered in spa-CC 1773 found in the small ruminant isolates were never found in the bovine isolates.

Isolates displaying the OV/OV' PFGE profiles and spa-CC 1773 were mostly classified into the agr group III (43 out of 45), whereas those with the " not OV/OV" "where more frequently classified into the agr groups I or II (56 out of 63).

\subsection{Hybridization and $P C R$ results.}

In first place, the DNA microarray data were used to screen and classify the genes as "present", "absent/divergent" or "not interpretable". The results obtained by DNA microarray and PCR analysis were compared for 38 distinct genes. Seventy-eight percent of the tested genes gave the same results by both techniques, whereas $14 \%$ was discordant. In case of doubt, some PCR results were confirmed two or more times. When the results between DNA microarray and PCR were discordant, only the positive results, except for SAV0812 (Table2), 
were taken into account into the final statistical analysis, after elimination of all possible artifacts.

250 One hundred and fifteen virulence-associated genes or alleles $(61 \%)$ defined in this study 251 were present in at least $90 \%$ of the S. aureus isolates. In contrast, 15 genes and alleles (8\%) 252 were absent in more than $90 \%$ of the isolates (supplementary data). Thirty-seven genes or 253 alleles (bsaD, capH-K, fnbB, hsdS, vwb, lpl2, lpl3, lpl5, lpl6, lpl7, SAV0288, SAV0368, 254 SAV0370, SAV1130, SAV1166, SAV1602, SAV1945, sdrC, sdrD, splA-D, splF, cna, map255 ND2C, seb, sed, set 15, set16, set 19, set21, agr group II) were not informative since they were 256 not statistically associated to any subset of $S$. aureus isolates. These genes were present or were "not interpretable" by DNA microarray analysis for more than $20 \%$ of isolates. Twentyfour genes or alleles $(12.8 \%)$ were found significantly associated with the PFGE group OV/OV'/spa-CC 1773 or with isolates obtained from small ruminant species (sheep and goats versus cows). Results are summarized in Table 2 and Table 3.

261 On the other hand, no genes were found statistically associated with nasal carriage isolates 262 versus mastitis isolates from dairy sheep in the same geographical location (southeast of 263 France). 


\section{Discussion}

A combined PCR and single-dye microarray approach allowed to screen for the presence of 190 genes among 108 S. aureus isolates, including some from the previously characterized OV/OV' lineage (Vautor et al., 2003; Vautor et al., 2005). To gain insight into the host specificity of $S$. aureus isolates, the gene patterns observed in isolates from cows and small ruminants were compared. The results were also examined in terms of geographical and tissue specificity.

From a technical point of view, most probably a one-colour-dye microarray is inferior to a two-colour one but, at a reasonable cost it made possible the screening of more than one hundred isolates for 190 genes. In some circumstances, the microarray data were not exploitable due to high background, artifacts or because differences between the positive and the negative results were considered as: "not interpretable". Another limitation of the study was that primers and probes used for PCR and microarrays could not be systematically chosen to match the same gene locations, which could explain some of the discordant results. Besides, allelic variations between veterinary $S$. aureus isolates and the Mu50 strain that was used to design most microarray probes could have occur.

\subsection{Regional diversity in S. aureus sheep isolates.}

A major lineage of $S$. aureus (PFGE group OV/OV' and spa-CC 1773) has been identified to be linked with a geographical region (isolates from sheep in southeast of France). Mork et al., (2005a) and Aires-de-Sousa et al., (2007) carried out studies using PFGE on 905 and 14 isolates, respectively. They did not find any peculiar genotype related to the three dairy species. In another report on $384 \mathrm{~S}$. aureus isolates from sheep udders in four regions of Norway (Mork et al., 2005b), 59\% of the isolates belonged to five closely related pulsotypes, that differed from the OV/OV' type previously characterized in our laboratory (Vautor et al., 2003). 


\subsection{Agr group, PFGE group, spa clonal complex and lineage specific genes}

The agr group I and III represented $44 \%(47 / 108)$ and $46 \%(50 / 108)$ of the isolates, respectively. The predominance of the agr group III was the consequence of the overrepresentation of the isolates from the dairy sheep in the southeast of France (46/108). All but 2 isolates out of 45, with the OV / OV' PFGE profiles and spa-CC 1773, belonged to the $a g r$ group III. This observation is in agreement with Jarraud et al. (2002), who demonstrated a relationship between the genetic background of the strains and the agr allele group. In a study carried out by De Santis et al (2005) on strains isolated from sheep with subclinical mastitis in Sardinia, 26 strains ( $81 \%$ ) out of 32 belonged to the agr group III.

Two genes were more frequently found in isolates from the OV/OV' PFGE group/spa-CC 1773: lpl4 (coding for a probable lipoprotein) (Kuroda et al., 2001) and ssl6 (coding for a staphylococcal superantigen-like protein previously named set6). Interestingly, these two genes are localized in the same staphylococcal genomic island type I $v \mathrm{Sa} \alpha$ in strain Mu50. The SAV0812 gene, coding for a protein similar to a secreted von Willebrand factor-binding protein, was also specific for the OV/OV' PFGE group/spa-CC 1773. This gene is truncated in some strains (e.g. RF122, MW2, COL, NCTC8325, MRSA252, MSSA476). This may explain the discrepancies found between the microarray data and the PCR results (Table 2), since the microarray probe was located in the truncated part of the gene whereas the PCR primers were not. We found that the $\mathrm{OV} / \mathrm{OV}$ ' lineage was also characterized by the absence of three bacteriocin genes ( $b s a \mathrm{~A} 1, b s a \mathrm{~B}, b s a \mathrm{P})$. These genes are located in the same genomic island (type II vSa $\beta$ ) in strain MW2 and NCTC8325 (Baba et al., 2002).

\subsection{Tissue specificity of S. aureus virulence genes.}

No genes were found specific to the isolates collected from the nostrils of sheep in comparison to udder isolates. This is in agreement with Lindsay et al. (2006) who failed to find, in human isolates, any genes significantly associated with invasive isolates by comparing 61 community-acquired invasive isolates of $S$. aureus to 100 nasal carriage 
isolates from healthy donors. However, since our study was performed in field conditions, it is possible that $S$. aureus isolates belonging to the resident flora of the nostrils could not be detected due the overwhelming presence of $S$. aureus isolates that are present in the milking room atmosphere (Vautor et al., 2005).

\subsection{Host specificity of S. aureus virulence genes}

Small ruminant isolates had a set of genes that was not statistically found in bovine isolates. Among them there are the lpl1gene ( located in the genomic island of Mu50 type IvSa $\alpha$ and coding for a probable lipoprotein), and the SAV0876 gene (coding for a hypothetical integrated prophage-related protein). The leukotoxin lukF-PV-like component (LukF'-PV) is linked with $l u k \mathrm{M}$ (Kaneko et al., 1997) and was found with a higher frequency in small ruminants isolates. $L u k \mathrm{~F}^{\prime}-\mathrm{PV} / L u k \mathrm{M}$ is the most active $S$. aureus leukotoxin on bovine neutrophils (Barrio et al., 2006). This leukotoxin is of importance because phagocytosis by polymorphonuclear cells (PMNs) and macrophages is regarded as one of the most important defense mechanisms of the mammary gland. It has been shown that the small ruminant isolates were more leukotoxic for bovine PMNs than the bovine isolates, but PMNs of small ruminants were more resistant to $l u k \mathrm{M}$ than bovine PMNs. The higher amount of leukotoxins secreted by $S$. aureus isolates from small ruminants may be seen as an adaptation to the higher resistance of small ruminants PMNs to $l u k \mathrm{M}$ in comparison to bovine PMNs (Rainard et al., 2003). In addition, the cluster $\operatorname{sel}, \sec 3$ and $t s t$ (belonging to the toxic shocksyndrome toxin 1 island, SaPIm1) was more prevalent in small ruminants isolates. In another study, the gene encoding the toxic shock-syndrome protein was more frequently associated to veterinary strains (especially those causing mastitis), than to human isolates (van Leeuwen et al., 2005). It was also reported that these genes were significantly associated with small ruminant isolates in comparison to bovine ones, by studying isolates from various countries (Smyth et al., 2005; Vimercati et al., 2006). 
In contrast, small ruminant isolates statistically lacked different genes. The $a b i \mathrm{~F}$ gene (SAV0368 in Mu50) codes for an abortive infection phage resistance determinant (Garvey et al., 1995). The Abortive infection (Abi) systems, also called phage exclusion, is widespread in bacteria and a recent analysis indicates that Abis might have an additional role apart from conferring phage resistance (Chopin et al., 2005). In the dairy environment, there is a large biodiversity of the lactococcal phage population, so the acquisition of this $a b i \mathrm{~F}$ gene through lateral transfer is probable. However, there is no explanation about its lesser frequency in small ruminants isolates. The SAV2496 gene codes for a hypothetical protein belonging to surface proteins from Gram-positive cocci such as a cell wall surface anchor family protein, which also less frequent among isolates from small ruminants. The operon egc (enterotoxin gene cluster) comprises the five enterotoxin genes seg, sei, sem, sen, seo and two pseudogenes $\Psi$ ent 1 and $\Psi$ ent 2 . This cluster forms a putative nursery of superantigens in $S$. aureus (Jarraud et al., 2001). Smyth et al. (2005) found that the egc cluster (complete and incomplete) was present with a lower frequency amongst the small ruminants isolates in comparison to bovine ones, which was also observed in the present study. Some surveys on $S$. aureus human clinical isolates showed that egc cluster was coupled with clonal lineages (van Belkum et al., 2006). The $f h u \mathrm{D} 1$ gene (SAV0803 in Mu50) was less prevalent in the small ruminants isolates than in the bovine ones. This gene, coding for a receptor for the transport of ferric hydroxamate (source of iron), is redundant to $f h u \mathrm{D} 2$ (SAV2284 in Mu50) (Sebulsky et al., 2001) and may play a prominent role during the growth of $S$. aureus in the host udder.

In general terms, the mechanisms explaining the relative host-specificity of $S$. aureus are still unknown, and more studies on the protein production of the specific genes have to be realized.

\section{Acknowledgements}


The support of the Réseau National Génopole ${ }^{\mathrm{TM}}$ and of the CNRS (Centre National de la

Recherche Scientifique) are greatly appreciated.

We thank Dr J.P. Rossec, Dr K. Omoe, Dr J.L. Martel, Dr P. Mercier, and Dr J. Penades

for kindly providing some of the isolates used in this work. We acknowledge G. Rossi for his

excellent technical assistance and C. Thiéry for checking the manuscript for English language.

\section{Appendix A. Supplementary data.}

Supplementary data associated with this article can be found, in the online version, at doi:XXXXXXXj.vetmic.2008yyy .

\section{References}

Aires-de-Sousa, M., Parente, C.E., Vieira-da-Motta, O., Bonna, I.C., Silva, D.A., de Lencastre, H., 2007. Characterization of Staphylococcus aureus isolates from buffalo, bovine, ovine, and caprine milk samples collected in Rio de Janeiro State, Brazil. Appl. Environ. Microbiol. 73, 3845-3849.

Baba, T., Takeuchi, F., Kuroda, M., Yuzawa, H., Aoki, K., Oguchi, A., Nagai, Y., Iwama, N., Asano, K., Naimi, T., Kuroda, H., Cui, L., Yamamoto, K., Hiramatsu, K., 2002. Genome and virulence determinants of high virulence community-acquired MRSA. The Lancet 359, 1819-27.

Barrio, M.B., Rainard, P., Prevost, G., 2006. LukM/LukF'-PV is the most active Staphylococcus aureus leukotoxin on bovine neutrophils. Microbes. Infect. 8, 20682074.

Becker, K., Roth, R., Peters, G., 1998. Rapid and specific detection of toxigenic Staphylococcus aureus: use of two multiplex PCR enzyme immunoassays for amplification and hybridization of staphylococcal enterotoxin genes, exfoliative toxin genes, and toxic shock syndrome toxin 1 gene. J. Clin. Microbiol. 36, 2548-2553.

Brazma, A., Parkinson, H., Sarkans, U., Shojatalab, M., Vilo, J., Abeygunawardena, N., Holloway, E., Kapushesky, M., Kemmeren, P., Lara, G.G., Oezcimen, A., Rocca-Serra, P., Sansone, S.A., 2003. ArrayExpress--a public repository for microarray gene expression data at the EBI. Nucleic Acids Res. 31, 68-71.

Chopin, M.C., Chopin, A., Bidnenko, E., 2005. Phage abortive infection in lactococci: variations on a theme. Curr. Opin. Microbiol. 8, 473-479. 
De Santis, E., Mureddu, A., Mazzette, R., Scarano, C., Bes, M., 2005. Detection of enterotoxins and virulence genes in Staphylococcus aureus strains isolated from sheep with subclinical mastitis, In H. Hogeveen (ed.), Mastitis in dairy production, current knowledge and future solutions, pp. 504-510.

Garvey, P., Fitzgerald, G.F., Hill, C., 1995. Cloning and DNA sequence analysis of two abortive infection phage resistance determinants from the lactococcal plasmid pNP40. Appl. Environ. Microbiol. 61, 4321-4328.

Gilot, P., Lina, G., Cochard, T., Poutrel, B., 2002. Analysis of the genetic variability of genes encoding the RNA III-activating components Agr and TRAP in a population of Staphylococcus aureus strains isolated from cows with mastitis. J. Clin. Microbiol. 40, 4060-4067.

Goh, S.H., Byrne, S.K., Zhang, J.L., Chow, A.W., 1992. Molecular typing of Staphylococcus aureus on the basis of coagulase gene polymorphisms. J. Clin. Microbiol. 30, 16421645 .

Jarraud, S., Peyrat, M.A., Lim, A., Tristan, A., Bes, M., Mougel, C., Etienne, J., Vandenesch, F., Bonneville, M., Lina, G., 2001. egc, a highly prevalent operon of enterotoxin gene, forms a putative nursery of superantigens in Staphylococcus aureus. J. Immunol. 166, 669-677.

Jarraud, S., Mougel, C., Thioulouse, J., Lina, G., Meugnier, H., Forey, F., Nesme, X., Etienne, J., Vandenesch, F., 2002. Relationships between Staphylococcus aureus genetic background, virulence factors, $a g r$ groups (alleles), and human disease. Infect. Immun. 70, 631-641.

Kaneko, J., Muramoto, K., Y. Kamio, Y., 1997. Gene of LukF-PV-like component of PantonValentine leukocidin in Staphylococcus aureus P83 is linked with lukM. Biosci. Biotechnol. Biochem. 61, 541-544.

Kuhn, G., Francioli, P., Blanc, D.S., 2006. Evidence for clonal evolution among highly polymorphic genes in methicillin-resistant Staphylococcus aureus. J. Bacteriol. 188, 169-178.

Kuroda, M., Ohta, T., Uchiyama, I., Baba, T., Yuzawa, H., Kobayashi, I., Cui, L., Oguchi, A., Aoki, K., Nagai, Y., Lian, J., Ito, T., Kanamori, M., Matsumaru, H., Maruyama, A., Murakami, H., Hosoyama, A., Mizutani-Ui, Y., Takahashi, N.K., Sawano, T., Inoue, R., Kaito, C., Sekimizu, K., Hirakawa, H., Kuhara, S., Goto, S., Yabuzaki, J., Kanehisa, M., Yamashita, A., Oshima, K., Furuya, K., Yoshino, C., Shiba, T., Hattori, M., Ogasawara, N., Hayashi, H., Hiramatsu, K., 2001. Whole genome sequencing of meticillin-resistant Staphylococcus aureus. Lancet 357, 1225-1240.

Lindsay, J.A., Moore, C.E., Day, N.P., Peacock, S.J., Witney, A.A., Stabler, R.A., Husain, S.E., Butcher, P.D., Hinds, J., 2006. Microarrays reveal that each of the ten dominant lineages of Staphylococcus aureus has a unique combination of surface-associated and regulatory genes. J. Bacteriol. 188, 669-676.

Monday, S.R., Bohach, G.A., 1999. Use of multiplex PCR to detect classical and newly described pyrogenic toxin genes in staphylococcal isolates. J. Clin. Microbiol. 37, 34113414 . 
Mork, T., Tollersrud, T., Kvitle, B., Jorgensen, H.J., Waage, S., 2005. Comparison of Staphylococcus aureus genotypes recovered from cases of bovine, ovine, and caprine mastitis. J. Clin. Microbiol. 43, 3979-3984.

Mork, T., Tollersrud, T., Kvitle, B., Jorgensen, H.J., Waage, S., 2005. Genetic diversity of Staphylococcus aureus isolated from ovine intramammary infections in Norway. Vet. Microbiol. 106, 265-273.

Peacock, S.J., Moore, C.E., Justice, A., Kantzanou, M., Story, L., Mackie, K., O'Neill, G., Day, N.P., 2002. Virulent combinations of adhesin and toxin genes in natural populations of Staphylococcus aureus. Infect. Immun. 70, 4987-4996.

Rainard, P., Corrales, J.C., Barrio, M.B., Cochard, T., Poutrel, B., 2003. Leucotoxic Activities of Staphylococcus aureus Strains Isolated from Cows, Ewes, and Goats with Mastitis: Importance of LukM/LukF'-PV Leukotoxin. Clin. Diagn. Lab. Immunol. 10, 272-277.

Rouillard, J.M., Herbert, C.J., Zuker, M., 2002. OligoArray: genome-scale oligonucleotide design for microarrays. Bioinformatics. 18, 486-487.

Rozen, S., Skaletsky, H,. 2000. Primer3 on the WWW for general users and for biologist programmers. Methods Mol. Biol. 132, 365-386.

Sebulsky, M.T., Heinrichs, D.E., 2001. Identification and characterization of $f h u \mathrm{D} 1$ and $f h u \mathrm{D} 2$, two genes involved in iron-hydroxamate uptake in Staphylococcus aureus. J. Bacteriol. 183, 4994-5000.

Smyth, D.S., Hartigan, P.J., Meaney, W.J., Fitzgerald, J.R., Deobald, C.F., Bohach, G.A., Smyth, C.J., 2005. Superantigen genes encoded by the egc cluster and SaPIbov are predominant among Staphylococcus aureus isolates from cows, goats, sheep, rabbits and poultry. J. Med. Microbiol. 54, 401-411.

Stephan, R., Annemuller, C., Hassan, A.A., Lammler, C., 2001. Characterization of enterotoxigenic Staphylococcus aureus strains isolated from bovine mastitis in northeast Switzerland. Vet. Microbiol. 78, 373-382.

Straub, J.A., Hertel, C., Hammes, W.P., 1999. A 23S rDNA-targeted polymerase chain reaction-based system for detection of Staphylococcus aureus in meat starter cultures and dairy products. J. Food Prot. 62, 1150-1156.

Van Belkum, A., Melles, D.C., Snijders, S.V., van Leeuwen, W.B., Wertheim, H.F., Nouwen, J.L., Verbrugh, H.A., Etienne, J., 2006. Clonal distribution and differential occurrence of the enterotoxin gene cluster, egc, in carriage- versus bacteremia-associated isolates of Staphylococcus aureus. J. Clin. Microbiol. 44, 1555-1557.

Van Leeuwen, W.B., Melles, D.C., Alaidan, A., al Ahdal, M., Boelens, H.A., Snijders, S.V., Wertheim, H., van Duijkeren, E., Peeters, J.K., van der Spek, P.J., Gorkink, R., Simons, G., Verbrugh, H.A., van Belkum, A., 2005. Host- and tissue-specific pathogenic traits of Staphylococcus aureus. J. Bacteriol. 187, 4584-4591.

Van Wamel, W. J., Rooijakkers, S.H., Ruyken, M., van Kessel, K.P., van Strijp, J.A., 2006. The innate immune modulators staphylococcal complement inhibitor and chemotaxis inhibitory protein of Staphylococcus aureus are located on beta-hemolysin-converting bacteriophages. J. Bacteriol. 188, 1310-1315. 


\section{9}

Vautor, E., Abadie, G., Guibert, J.M., Chevalier, N., Pepin, M., 2005. Nasal carriage of Staphylococcus aureus in dairy sheep. Vet. Microbiol. 106, 235-239.

Vautor, E., Abadie, G., Guibert, J.M., Huard, C., Pepin, M. 2003. Genotyping of Staphylococcus aureus isolated from various sites on farms with dairy sheep using pulsed-field gel electrophoresis. Vet. Microbiol. 96, 69-79.

Vimercati, C., Cremonesi, P., Castiglioni, B., Pisoni, G., Boettcher, P.J., Stella, A., Vicenzoni, G., Moroni, P., 2006. Molecular typing of Staphylococcus aureus isolated from cows, goats and sheep with intramammary infections on the basis of gene polymorphisms and toxins genes. J. Vet. Med .B Infect. Dis. Vet. Public Health 53, 423-428. 
Table 1

PFGE Patterns, spa-CC and agr groups of 108 Staphylococcus aureus isolates included in this study

\begin{tabular}{|c|c|c|c|c|c|c|c|}
\hline \multirow{2}{*}{$\begin{array}{l}\text { Animal species } \\
\text { (Region) }\end{array}$} & \multirow{2}{*}{$\begin{array}{c}\text { Clinical features } \\
\text { or origins }\end{array}$} & \multirow{2}{*}{$\begin{array}{l}\text { Isolates } \\
\text { (n) }\end{array}$} & \multirow{2}{*}{ PFGE Patterns } & \multicolumn{4}{|c|}{$a g r$ group } \\
\hline & & & & I & II & III & IV \\
\hline \multirow{6}{*}{$\begin{array}{l}\text { Dairy sheep } \\
\text { (Southeast) }\end{array}$} & Subclinical & 16 & $\mathrm{OV} / \mathrm{OV}^{\mathrm{a}}$ & 0 & 0 & 14 & 0 \\
\hline & mastitis & 10 & Not $\mathrm{OV} / \mathrm{OV}^{, \mathrm{b}}$ & 1 & 1 & 0 & 0 \\
\hline & Nacol corrioge & 21 & $\mathrm{OV} / \mathrm{OV}$ & & 0 & 13 & 0 \\
\hline & Nasal Cantage & 21 & Not OV/OV' & 7 & 1 & 0 & 0 \\
\hline & Others & & $\mathrm{OV} / \mathrm{OV}$ & 0 & 0 & 5 & 0 \\
\hline & $\begin{array}{l}\text { (abscesses, air, } \\
\text { clinical mastitis) }\end{array}$ & 9 & Not OV/OV', & 2 & 0 & 2 & 0 \\
\hline \multirow{3}{*}{$\begin{array}{l}\text { Dairy sheep } \\
\text { (Southwest) }\end{array}$} & Subclinical & 18 & $\mathrm{OV} / \mathrm{OV}$ & 1 & 0 & 3 & 0 \\
\hline & mastitis & & Not OV/OV', & 12 & 2 & 0 & 0 \\
\hline & Clinical mastitis & 1 & Not OV/OV' & 1 & 0 & 0 & 0 \\
\hline \multirow{2}{*}{ Goats } & Subclinical & 22 & $\mathrm{OV} / \mathrm{OV}$ & 0 & 1 & 8 & 0 \\
\hline & mastitis & & Not OV/OV' & 8 & 3 & 2 & 0 \\
\hline Cows & $\begin{array}{c}\text { Subclinical } \\
\text { mastitis }\end{array}$ & 21 & Not OV/OV' & 15 & 3 & 3 & 0 \\
\hline \multirow{2}{*}{ Total } & & & $\mathrm{OV} / \mathrm{OV}$ & 1 & 1 & 43 & 0 \\
\hline & & & not $O V / O V$ & 46 & 10 & 7 & 0 \\
\hline
\end{tabular}

a OV and OV' were PFGE profiles belonging to the same group $(n=45)$. The OV/OV' PFGE profiles were determined according to Vautor et al. (2003). There were 12 spa types among the 45 isolates. These OV/OV' patterns belonged to the spa-clonal complex spa-CC 1173 $(\mathrm{n}=43)$, and two other spa-CC 2678 and spa-type 3572.

b Not OV/OV' were other PFGE profiles which were not predominant among the 61 patterns $(\mathrm{n}=63)$ (data not shown). There were 36 spa types among the 63 isolates. These PFGE profiles did not have a predominant spa-clonal complex: spa-CC $2678(\mathrm{n}=25)$, spa-CC 1773 $(\mathrm{n}=12)$, singleton $(\mathrm{n}=6)$, spa-CC $164(\mathrm{n}=4)$, spa-CC $359(\mathrm{n}=3)$, spa-CC $127(\mathrm{n}=3)$, spa type3585/excluded $(\mathrm{n}=1)$, no founder $(\mathrm{n}=9)$. 


\section{Table 2}

Genes or alleles statistically associated with $S$. aureus strains clustered in PFGE pattern OV/OV'/spa-CC 1773 or "not OV/OV"'(DNA microarray data and PCR results)

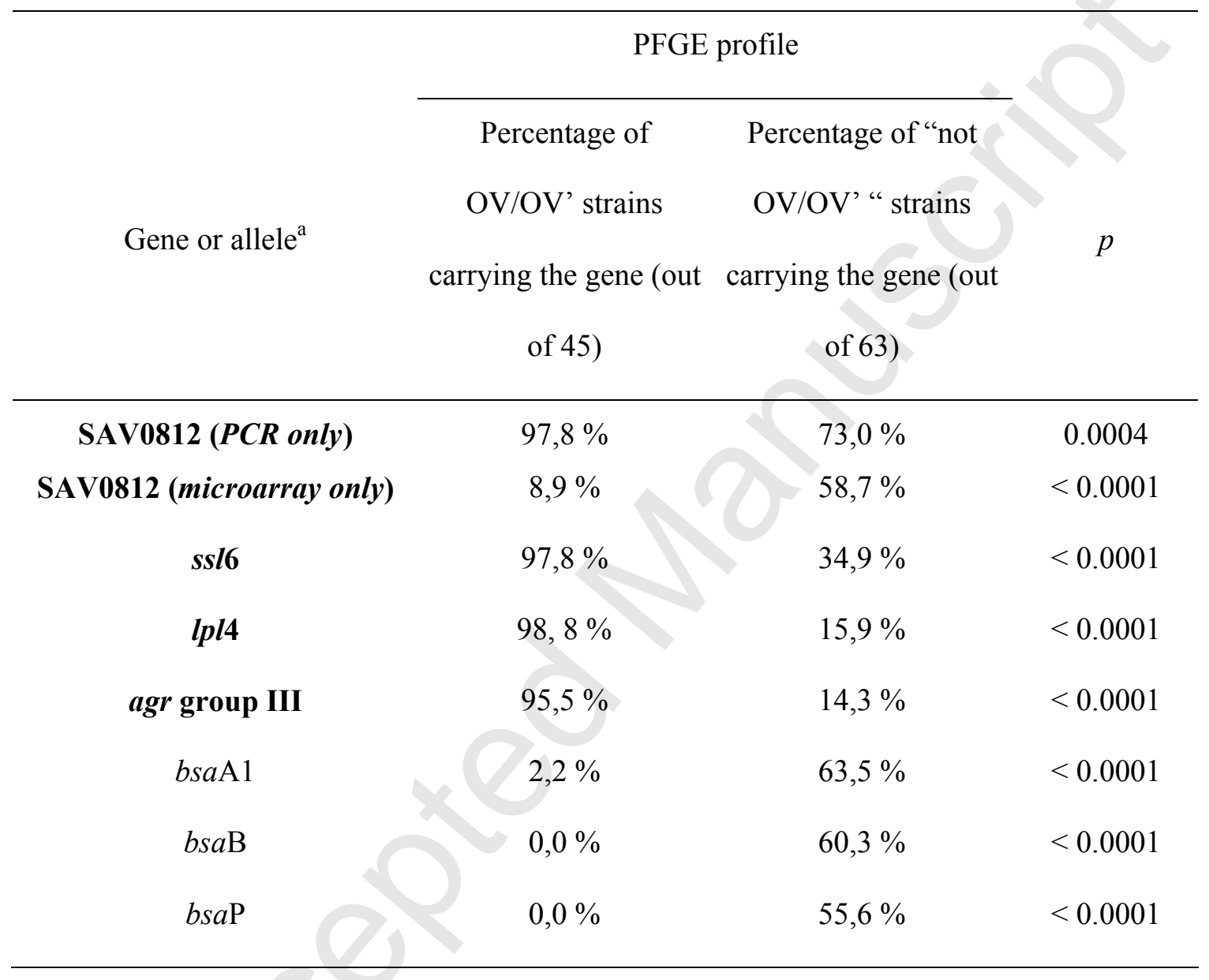

${ }^{\mathrm{a}}$ In bold characters: genes specific to PFGE pattern OV/OV'/spa-CC 1773. 


\section{Table 3}

Genes or alleles statistically associated with $S$. aureus isolates from small ruminants versus those coming from cows (DNA microarray data and PCR results)

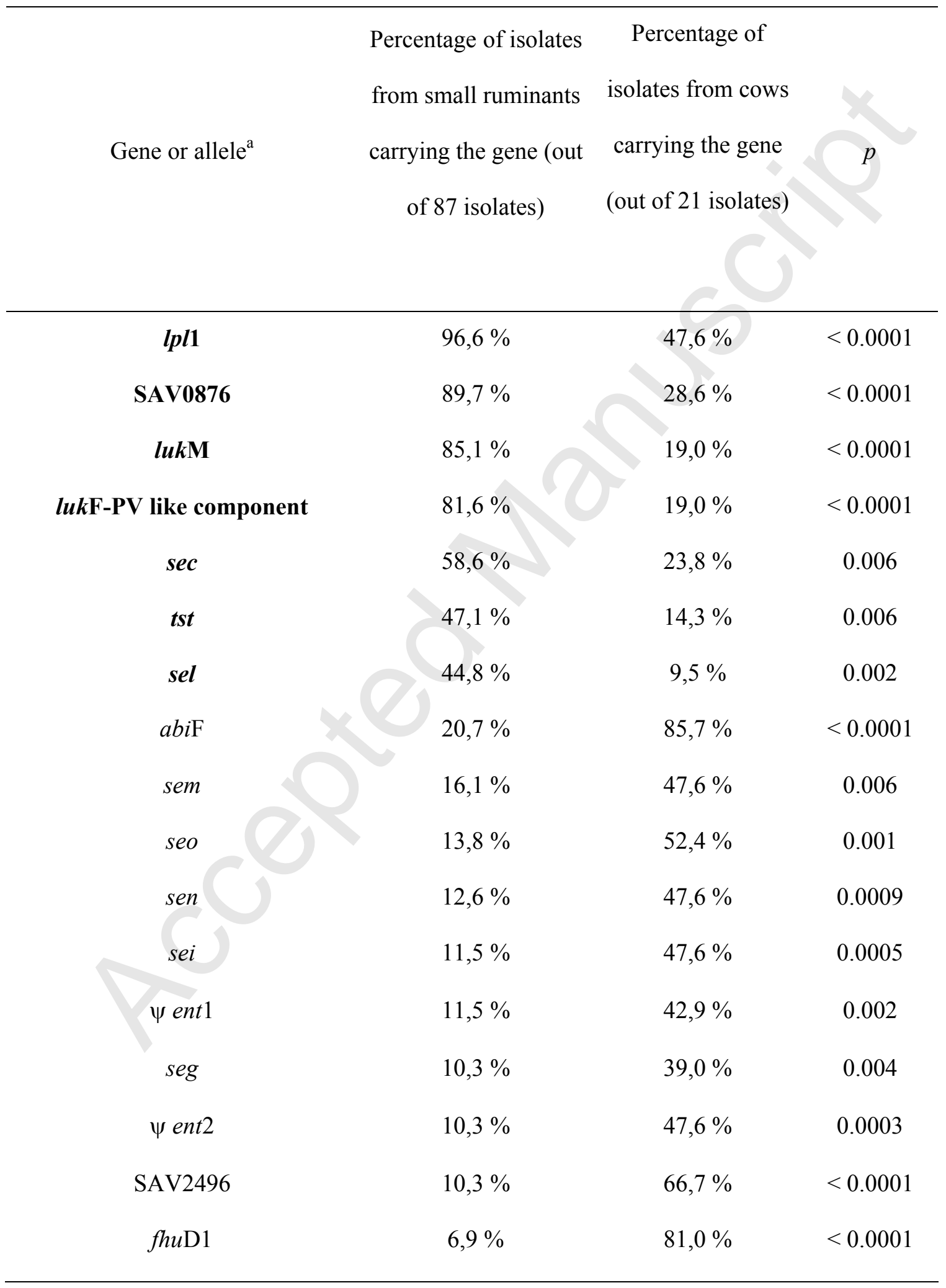

${ }^{\mathrm{a}}$ In bold characters: genes specific to small ruminants (sheep and goats). 